\title{
Use of Theoretical Models in Family Therapy: Focus on Social Constructionism ${ }^{1}$
}

\author{
Gabriela Silveira de Paula-Ravagnani ${ }^{2}$ \\ Universidade de São Paulo, \\ Ribeirão Preto-SP, Brazil
}

\author{
Carla Guanaes-Lorenzi \\ Universidade de São Paulo, \\ Ribeirão Preto-SP, Brazil
}

\author{
Emerson Fernando Rasera \\ Universidade Federal de Uberlândia, \\ Uberlândia-MG, Brazil
}

\begin{abstract}
In the field of family therapy (FT), theoretical and methodological perspectives coexist. This article aims to comprehend how family therapists use different theories, especially social constructionism. We describe a qualitative study, carried out through semi-structured and individual interviews with 14 Brazilian family therapists, men and women. Our analysis and discussion present four types of discourse by which the participants combine theoretical perspectives: conciliatory-constructionist, conciliatory-reflexive, conciliatory-descriptive and eclectic. The analysis presents features that characterize and differentiate each discourse, and implications they have on the participants' practice. We conclude that the combination of theories is an effort to enhance clinical practice, at the same time as it creates tensions in the FT field. This article invites family therapists to construct practices based on an epistemological investigation, by which they will be able to identify theoretical premises that guide their actions, as an effort to achieve congruence between practices and the theories behind them.
\end{abstract}

Keywords: family therapy, clinical psychology, social constructionism, theories

\section{A Utilização de Modelos Teóricos na Terapia Familiar: Foco no Construcionismo Social}

\begin{abstract}
Resumo: No campo da terapia familiar (TF) coexistem perspectivas teóricas e metodológicas. O objetivo deste artigo é compreender como terapeutas familiares utilizam diferentes teorias da TF, especialmente, o construcionismo social. Este estudo possui natureza qualitativa, e foi realizado a partir de entrevistas individuais semi-estruturadas, com 14 terapeutas familiares brasileiros, homens e mulheres. A análise e discussão apresentam quatro discursos pelos quais os terapeutas combinam perspectivas teóricas: conciliatório-construcionista, conciliatório-reflexivo, conciliatório-explicativo e eclético. A análise apresenta aspectos que os caracterizam e diferenciam, e implicações que possuem na prática dos terapeutas. Concluímos que a combinação de teorias busca enriquecer a prática clínica, ao mesmo tempo em que gera tensões no campo da TF. O artigo convida os terapeutas a construírem práticas orientadas por uma investigação epistemológica, por meio das quais podem identificar os pressupostos teóricos que norteiam suas ações, em busca de congruência entre as práticas empregadas e as teorias que as embasam.
\end{abstract}

Palavras-chave: terapia familiar, psicologia clínica, construcionismo social, teorias

\section{EI Uso de Modelos Teóricos en la Terapia Familiar: Foco en el Construccionismo Social}

\begin{abstract}
Resumen: En el campo de la terapia familiar (TF) coexisten perspectivas teóricas y metodológicas. El objetivo de este artículo es comprender cómo los terapeutas familiares utilizan teorías de la TF, especialmente, el construccionismo social. Es un estudio cualitativo, realizado a partir de entrevistas semiestructuradas, con 14 terapeutas familiares brasileños, hombres y mujeres. El análisis y discusión presentan cuatro discursos en que terapeutas combinan teorías: conciliatorio-construccionista, conciliatorio-reflexivo, conciliatorio-explicativo e ecléctico. El análisis presenta aspectos que los caracterizan y diferencian, e implicaciones en la práctica de los terapeutas. Concluimos que la combinación de teorías busca enriquecer la práctica clínica y genera tensiones en el campo de la TF. El artículo invita terapeutas a la construcción de prácticas orientadas por una investigación epistemológica, a través de las cuales puedan identificar presupuestos teóricos que guían sus acciones, buscando congruencia entre las prácticas adoptadas y las teorías que las fundamentan.
\end{abstract}

Palabras clave: terapia familiar, psicología clínica, construccionismo social, teorías

\footnotetext{
${ }^{1}$ Paper deriving from primary author's Master's thesis, under the supervision of the second author, with the cooperation of the third author, defended in 2015 in the Graduate Program in Psychology at Faculdade de Filosofia, Ciências e Letras de Ribeirão Preto, Universidade de São Paulo.

Support: São Paulo Research Foundation (FAPESP - Grant 2012/17502-6)

${ }^{2}$ Correspondence address: Gabriela Silveira de Paula-Ravagnani. Av. Bandeirantes, 3900, Monte Alegre. CEP: 14049-901. Ribeirão Preto-SP, Brazil. E-mail: paula.gabrielasr@gmail.com
}

Family therapy (FT), as a knowledge field and therapeutic modality, proposes the understanding of human experiences from a relational perspective. Its establishment in the scientific context traces back to the 1950's, when mental health experts in the United States and Europe started to acknowledge the influence of social, economic, cultural and fa- 
mily factors on the emergence and maintenance of psychiatric disorders (Rhodes, 2012).

From the start, the constitution of FT was based on different theoretical and epistemological perspectives, outlining an interdisciplinary field without a unifying paradigm. Both the systemic and psychoanalytical perspectives were established most strongly in the FT field.

The psychoanalytical frameworks developed based on concepts proposed by Sigmund Freud, Melanie Klein, Donald Winnicott, José Bleger, Enrique Pichon-Rivière and the studies involving families of schizophrenic patients in the 1940's and 1950 's. The psychoanalytical propositions for family care replaced the individual care model for members of the same family by different therapists by having a single therapist attending to the entire family group (Flaskas, 2016). This change focuses on the unconscious functioning of the family - as emphasized in the American and English perspectives - or the bond configurations of the family, as the French and Latin-American perspectives emphasize (Nicolò, Benghozi, \& Lucarelli, 2014).

The proposals of cybernetics and systemic thinking influenced the construction of the theoretical and practical body of the systemic frameworks. In the human and social sciences, these ideas permitted looking at the family as a system, moving the focus to the reciprocal and interdependent interaction among the members. Hence, the therapist's work changed from the symptoms presented to the relations that produce and sustain them (Kaslow, 2011; Lebow, 2014). These changes expanded the dominant individual focus in mental health practices and FT had the initial project of creating theories and practices focused on the families' relations and communication patterns (Breunlin \& Jacobsen, 2014).

In the 1980's, the propositions by Gregory Bateson, Heinz von Foerster, Humberto Maturana and Francisco Varela changed the conceptions on the knowledge construction process (Flaskas, 2011). Hence, the systemic perspectives were influenced by constructivism and moved from an epistemology based on neutrality and objectivity to one that conceives the therapeutic change unit as the therapist-client system. This period is described as second-order cybernetics, in which the therapist began to take into consideration his/her own processes of creating knowledge about the family.

At the end of the 1980's and throughout the 1990's, systemic FT was influenced by the ideas of postmodernity. The definitions of postmodernity trace back to a hybrid field of study that consists of different authors and perspectives, distancing the possibility of a single consensus definition. What interests us is that the field of FT received influences from the postmodern conception of knowledge as a process that takes place through language practices, which are linked to the social contexts and discourses that circulate in the social midst (Sutherland \& Strong, 2011). The therapist gives up seeking "complete" knowledge, that is, that best expresses "the therapeutic process as it really is", in order to commit to the multiple knowledge construction forms. Hence, the therapist acts based on a collaborative stance in which he/she constructs knowledge with the clients through conversation (Anderson, 2012; Flaskas, 2011).
Social constructionism is one form to elaborate the postmodern criticism and particularly influenced the field of systemic FT (McNamee \& Gergen, 1992). Defined as a movement in science, it conceives the construction of the reality through the language practices, focusing on the negotiation and coordination processes among people, from which the meaning of the reality emerges (Gergen, 1985; Guanaes-Lorenzi, Moscheta, Corradi-Webster, \& Souza, 2014). From a constructionist perspective, the therapy is described as a dialogical process in which all participants (therapist and clients) engage in the joint construction of meanings, setting the limits and possibilities of the participants' actions, relations and creation of meanings (McNamee \& Gergen, 1992).

This brief theoretical-practical panorama evidences the multiple and diversified nature of FT. Echoing the multiple trends of FT in the international sphere, Brazilian studies appoint the range of theoretical-practical contributions family therapists use as part of their daily practice.

Ponciano and Féres-Carneiro (2006) analyzed the proceedings of four editions of the Brazilian Family Therapy Congress (1994, 1996, 1998, 2002). The presented studies were based on different theories, including: psychoanalysis, constructivism, systemic theory, psychodrama, social constructivism, existentialism and bioenergetics. The same authors (Féres-Carneiro \& Ponciano, 2005) highlight the existing diversity in the Brazilian context of FT, affirming that the articulation of theoretical frameworks is characteristic of the historical development of FT in the country. More recently, the study by Prati and Koller (2012) mapped family therapists' practices in Brazil and indicates a movement among professionals towards the integration of theories in clinical practices. The systemic, psychoanalytic and post-modern propositions stand out amongst the participants' choices.

These empirical research results in the Brazilian context echo a trend towards the integration of theoretical and practical frameworks, described as an integrative movement that has developed in an increasingly sophisticated manner in FT and Psychology since the 1980's (Lebow, 1997, 2014; Snyder \& Balderrama-Durbin, 2012). The integrative movement creates new possibilities by offering practical and theoretical resources to the therapist, who faces multiple and complex demands in daily clinical practice. At the same time, it raises challenges and tensions, as the criteria to articulate theories and practices are hardly clear and defined (Dickerson, 2010; Féres-Carneiro \& Ponciano, 2005).

The current international literature indicates that social constructionism has influenced, to a greater or lesser extent, all practices in systemic family therapy (Flaskas, 2011; Kaslow, 2011). At the same time, a combined use of theoretical models is observed in Brazil, which creates a need to understand the place of social constructionism and how family therapists have used it. Hence, this article aims to understand how family therapists use different FT propositions in their clinical practice, particularly social constructionism. This study will grant an understanding of how social constructionism is disseminated in the clinical context. 


\section{Method}

This qualitative study was developed based on the contributions of the social constructionist movement for scientific practice and, as such, was guided by some main premises. We consider research as a social practice, that is, knowledge production is considered as a social, historical and culturally situated activity, intersected by the researcher's subjectivity. The studies are focused on the practical use of language in human activities, granting visibility to how it creates, sustains, reproduces and transforms the social realities. And the method is understood as a possibility to construct objectivities and versions of the world, instead of a device that allows us to "discover" the nature of the objective world (Gergen, 1985, 2015; McNamee \& Hosking, 2012; Spink \& Menegon, 1999/2013).

We use the discursive practices analysis proposed in the field of Social Psychology (Spink \& Medrado, 1999/2013). The discursive practices refer to the language use in the interactions, when the discourses the people use to give meaning to the world and to their experiences may gain new meanings or be reproduced (Spink \& Medrado, 1999/2013).

The definition of the discursive practices is interwoven in the discourse concept. Burr (2003) defines discourse as a set of meanings, metaphors, histories, images and other elements that allow us to create versions about facts, objects and phenomena. Hence, the discourse remits to the linguistic regularities and the institutionalized use of language (Spink \& Medrado, 1999/2013). As our study is focused on the performance dimension of language, we aim to grant visibility to the implications of the meanings produced with the participants and the discourse permeating these meanings.

\section{Participants}

Fourteen family therapists participated in this research, male and female, psychologists, who are considered disseminators of the social constructionist ideas in FT in Brazil, in view of the inclusion criteria described next. We outlined the following criteria to include the participants: (1) being a family therapist, psychologist and teacher responsible for teaching social constructionist ideas in training courses in FT affiliated with the Brazilian Association of Family Therapy (ABRATEF) in the states of São Paulo and Rio de Janeiro. We defined these states based on the study by Ponciano and Féres-Carneiro (2006), who indicate them as the hubs of research production and participation in FT congresses; and (2) figuring among the five authors who most published in the journal Nova Perspectiva Sistêmica (NPS) between 2008 and 2013. This journal is widely distributed among Brazilian family therapists and has prioritized the discussion of practices based on systemic, narrative and social constructionist proposals. The participants were contacted by e-mail and invited to participate in the study.

All participants are family therapists engaged in teaching in FT training courses. The length of clinical practice ranges between five and thirty years. After graduating in Psy- chology, the participants started their career using different theoretical approaches. They sought training in FT after they had experienced moments when their interventions - whether in the community or in psychotherapy - required that they handled issues involving the family in a broader sense, and their practical and theoretical framework seemed insufficient to cope with the situation. Only one participant sought FT training soon after graduating in Psychology.

\section{Instruments}

The instrument to construct the research corpus was a semistructured interview script, which explored: the contact history with social constructionism; how the constructionist contributions are used in clinical practice; and challenges and potentials faced in the practice based on the use of these ideas.

\section{Procedure}

Data collection. The constitution of the research corpus was based on individual interviews, according to the script described above. The primary author held the interviews at the place and time the participants found most convenient. The interviews were audio recorded and fully transcribed.

Data analysis. We consider the interview as a discursive practice (Pinheiro, 2013), corresponding to an interaction between the researcher and the participant, in which the meanings and versions of the reality are produced through the constant negotiation of positions among the participants. The corpus analysis started with the interview transcription, when the researcher had contact with important elements to attribute meaning to them, such as intonations and voice inflections (Guanaes, 2006). Next, the material was subject to in-depth reading to get more familiar with the corpus.

By this analysis process, we identified changes that emerged in the participants' clinical practice by the contact with social constructionist ideas. Therefore, we name two different discourses through which social constructionism influenced the relation with other theoretical models. These were analyzed based on their characteristics and distinctive elements and their consequences in the therapists' practice.

In the discussion of the results, we highlight excerpts from the interviews that illustrate each discourse described. The use of these excerpts granted visibility to the fact that the participants move between different forms of discourse in the course of the interviews. Thus, the analyses we present are not focused on particular people, but on the discourse they use to grant meaning to the contributions of social constructionism to clinical practice.

\section{Ethical Considerations}

The research was developed in compliance with the ethical guidelines of Resolution 196/96 for studies involving human beings, in force at the time the study was developed. Approval was obtained from the Research Ethics Committee at Faculdade de Filosofia, Ciências e Letras de Ribeirão Preto-USP, under CAAE protocol 06338412.4.0000.5407. Before participating in the interview, the therapists received 
information on the nature of the interview, the voluntary nature of their participation, the confidentiality and secrecy of the information and signed an Informed Consent Form. All names used in this article are fictional.

\section{Results and Discussion}

\section{The Conciliatory Discourse}

We use the term conciliatory to describe discourses in which a therapist actively seeks resources in different explanatory models to improve his/her clinical management. In this line, we describe three forms of the conciliatory discourse: conciliatory-constructionist, conciliatory-reflexive and conciliatory-explanatory.

Conciliatory-constructionist discourse. This term refers to the discourse in which the therapist only uses theoretical frameworks sensitive to the social constructionist propositions - based on the interviews, we more clearly observe the ideas by Andersen (1991), Anderson (2012) and White (2007). We consider that that is a conciliatory form to use theoretical models, given the existence of different authors and proposals that are either openly affirmed as social constructionist or considered by authors and specialists in the area as having a constructionist sensitivity. Below is an interview excerpt:

Elisa: Today, I practice and move very calmly between the narrative and the collaborative practices. For me, they are absolutely practices guided by social constructionism... So, among the collaborative practices, which are organized by the social constructionist ideas and, I'd say, in a more extreme purist form of what we could think as a clinical action, until the narrative practices, which have some more structure, of devising some conversation forms $a$ priori, right? The transformative conversations. I move very well, and I see it as epistemological coherence.

As the excerpt illustrates, the use of the conciliatory-constructionist discourse is the therapist's option to structure her clinical practice based on theories and practices based on the social constructionist propositions. Using the participant's term, the justification for this discourse comes from the perspective of epistemological coherence, a position that incorporates only theoretical propositions sensitive to the social constructionists' premises. In the excerpts that illustrate the use of this discourse, the therapist considers that the social constructionism does not offer a single care model, but a sensitivity that guides the encounters with families. In her words:

Elisa: These [social constructionist] ideas came to legitimize that one could have truly transforming conversations.... organized by dialogical conversation... Within constructionism, the main emphasis I see is on how to cope with the voices, the distinct voices originating in the different traditions.
Guided by concepts like dialogue, polyphony, joint action, relational self and relational construction of reality (sic), the coherence of this discourse rests on the sensitivity to authors and premises that guide the therapist in theoretical as well as technical terms. That is so because, although constructionism is not proposed as an "approach" in the field of FT (Guanaes, 2006), the authors who develop and apply these ideas in the practical field end up offering models and practices that structure the therapist's work during the encounters with families, such as Andersen (1993), Anderson and Burney (n.d.) and White and Epston (1990), for example. According to the authors, these practices are not "recipes" to be used despite the particularities of family care, but end up being structured as reference guides for the professional's daily practice.

Conciliatory-reflexive discourse. We describe the conciliatory-reflexive discourse as the discourse in which the therapists use the social constructionist ideas as a resource to relate with other theoretical models of FT. This discourse differs from the conciliatory-constructionist discourse because the clinical practice is not exclusively based on social constructionist ideas. Differently, it is a discourse that uses the constructionist ideas as triggers of critical reflections on the use of different theoretical models in therapeutic practice. This discourse departs from the understanding of constructionism as a metatheory, that is, a form of expressing the knowledge production process in the social exchanges (Gergen, 1985). The following excerpt illustrates this discourse:

Renata: It's like using some traditional systemic theories. You could even use them, right? But with a new look, a new posture. A posture that you're no longer the knowledge expert. So I use many techniques... for example, if I make a joint drawing, or even individual drawing.... those techniques, in principle, are not constructionists. That is, they aren't by themselves, right? But it's how we deal with them.... How I explore the contents once they emerge.

This excerpt exemplifies the use of a discourse in which different theoretical models are considered as resources the therapist has available to construct conversations with families. Like in the conciliatory-constructionist discourse, the use of this discourse is justified by the search for coherence. In the conciliatory-reflexive discourse, however, this coherence is defined distinctly, considering the theories as discursive constructions, which are not considered valid, correct and effective by themselves. Thus, in the conciliatory-reflexive discourse, the theories are considered possible openings for the therapeutic conversations, instead of determinant views of the family or its members. In that sense, the interest in using different technical and theoretical instruments lies in the possibility to construct transformative conversations with families.

Authors from the field of FT discuss the position of the therapist towards different explanatory models (Dickerson, 2010; McNamee, 2004; McNamee \& Gergen, 1992). Overall, the authors propose that, in a clinical practice sensitive to so- 
cial constructionism, the coordination of different theoretical models demands that these be considered conversational resources chosen based on the therapist's responsive and reflexive posture towards the clients and the conversational process. This implies that the ideas of distinct theoretical models be considered possibilities for discursive constructions about the world (instead of correct and truthful explanatory models), which can ensure the coherence of therapeutic practice.

Conciliatory-explanatory discourse. This term designates a discourse in which different theoretical models of FT offer the therapist feasible and reliable explanations on the phenomena observed in the therapeutic process. In this discourse, the explanations in a theoretical model are considered valid by themselves and used, in the therapeutic context, despite whom one talks to, the moment this conversation takes place and in what conditions. In the interviews, the use of the conciliatory-explanatory discourse articulates the social constructionism with theoretical models identified with the systemic approaches, both the traditional approaches and those influenced by second-order cybernetics.

In this discourse, the social construction proposition of knowledge is not considered a rupture in relation to the previous forms of understanding this phenomenon. Social constructionism figures together with other theoretical models as yet another model that, aside other approaches, constitutes the continuum in the development of the FT field. Below is an excerpt:

Researcher: And when you sought the constructionist ideas and maintained this contact throughout your career, how did you think the constructionism would be useful in your practice?

Nina: It's like I tell you, right? The thing was always in this attitude of finding out about the new frameworks, the new ways of thinking and, as I got into that and starting participating in the congress entitled "Construction-ing", those things, I started to identify... I don't think there's one... one line, right? "From here onwards I am a constructionist". Little by little we assimilate the aspects that are discussed, the postures we see, and we take our stand and start acting, right? Because things don't stop.... Researchers: And in your practice, do you combine constructionism with other perspectives or other approaches?

Nina: ....When I work with families and when there are children, and sometimes according to the problem raises, I bring plenty of aspects from constructivism.... the matter of the mental processes, mainly school difficulties, attention, irritability, some child behavior issues. Then I use, use drawing and things... I also try to analyze the child's development phase a bit in terms of logical thinking, and I often explain it to the parents, right?.... These evolutionary aspects I find important.

This excerpt exemplifies the main understanding of this discourse form: the validation attributed to one explanatory model does not invalidate or attribute a new meaning to others. In this particular excerpt, explanations from a social constructionist viewpoint, using their specific languages, do not invalidate explanations that depart from constructivist premises to understand the human being and vice-versa. Thus, clinical practice includes the different theoretical models as ways to understand families. Nevertheless, this approach entails a tension: how to work from a social constructionist perspective and, at the same time, elect the mental processes as reality?

Thus, we observe that the conciliatory-explanatory discourse emphasizes the contents of the different schools and approaches. In that discourse, the professionals who use contents from distinct schools to support their practice may work on more consistent bases. Since the focus on the theories' contents grants them the status of truth, we may affirm that the different theoretical models used by the therapist can be assessed only based on their own epistemological logic. That aspect can be discussed based on the following excerpt:

Cecilia: It is as if I felt there is something social constructionism granted me as a base, which is this: there are multiple forms of envisaging the situation, various viewpoints, this idea of construction, of personal experience. So it's as if that were the foundation, then in practice there are other authors... I criticize thinking that simply going through this [social constructionism] prepares a family therapist. Because I think it provides you with a worldview, right? A stance, and I think it provides you with instruments for the conversations. But I don't think that, if you get a pedagogue, a sociologist, any student and teach constructionism, you are preparing a family therapist. I think you have to think a lot about the family dynamics, the family functioning, on the three-generational aspect, the models, on what many authors proposed.

This discourse offers a particular view on how to enhance the therapists' practice by using different theoretical frameworks. In doing so, it creates some tensions in FT field. Social constructionism echoes a rupture in FT field by describing the knowledge construction process through language practices. This movement has been described as the "interpretative turn" in FT, which focuses on the dialogical nature of the therapeutic process and on the networks of meanings that people are immersed in (Flaskas, 2011). In this sense, the constructionist perspective in science permits considering that the theoretical models are discursive productions generated in the social exchange and validated by certain scientific communities (Gergen, 1985). This understanding invites the therapist to acknowledge the situated nature of the theories and their validity in relation to the context they emerge in. Hence, social constructionism proposes a discontinuity in relation to the individualist and essentialist traditions in the human and social sciences.

The conciliatory-explanatory discourse validates theoretical models deriving from distinct scientific traditions and, 
by doing so, seeks to enrich the therapist's clinical practice. As a result, it integrates mutually incompatible theories and techniques in terms of how they understand the person (theory of personality), the problems (pathology), and the change proposals (therapy) (Dickerson, 2010). This author claims that the conversation space shaped through different epistemological positions defines distinct action logics for the therapist. Hence, we consider that the conciliatory-explanatory discourse is informed by aspects of the social constructionist proposal for the therapeutic practice, but does not imply that the theoretical models gain a new meaning as discursive constructions.

\section{Eclectic Discourse}

In line with Dickerson (2010), we consider that eclecticism in the context of FT practice is characterized by the concomitant use of propositions originated in diverse schools and explanatory models. This use is characterized by the choice of those aspects that are considered better and more relevant among different frameworks. In the eclectic discourse we describe, the therapist uses different explanatory models and the theoretical and technical aspects he/she considers to adapt better to the situation he/she is dealing with.

The main aspect that distinguishes this discourse from the conciliatory discourses is the use of different propositions based on a juxtaposition, in which aspects from approaches belonging to distinct scientific traditions are grouped and used to explain the situations experienced in the therapeutic practice.

The conciliatory-explanatory discourse differs from the eclectic discourse because while the former uses distinct explanatory models that have the systemic theories as a common ground, the latter uses frameworks and theoretical models that share neither a theoretical nor an epistemological background. Below is an excerpt:

Researcher: So, from what I'm hearing, you do not close your practice in the voices of social constructionism only?....

Julia: That's right. Because I strongly believe in working on demand. Because I've learned to value this work we construct based on the other's demand, studying constructivism and social constructionism... At first, the studies on complexity were more disseminated, more discussed, so it made sense for me, right? A second important sense, which is: "yes, we should take care of the relationships, but the priority is what the other is asking, the demand presented, and 'how' we'll work depends on the context, on our preparation".... So that's what I try to teach the students, that they should expand their knowledge a lot, and they will probably adjust to a way of working that might be this [social constructionism], but they should not lose other aspects out of sight, which might be behavioral, intrapsychic, social. It's good that we see the human being as this more complex whose. I think that is fundamental nowadays.
As we can see, in this discourse, the consistency of practice grows directly proportional to the range of theoretical models that are part of the therapist's practice. Therefore, the professional acts inspired on a logic that links the quality of practice to the use of as many dimensions as possible to understand the human being - behavioral, intrapsychic, social. Hence, different explanatory models are juxtaposed and, on the whole, offer a view as complete as possible for the therapist.

In this sense, we highlight one important distinction needed when theoretical contributions are used concomitantly. On the one hand, the human being can be understood based on multiple dimensions (biological, physical, social, psychological, spiritual, etc.). To construct an integrated and articulated view on human experiences, it should be considered that these dimensions influence the individuals simultaneously. This understanding echoes, for example, the complexity studies proposed by the French philosopher Edgar Morin, whom Julia refers to throughout the interview as an important author that influences her practice.

On the other hand, differently from this understanding, the eclectic discourse validates the use of different perspectives or theoretical models to construct practices focused on a single dimension of human experience: the psychological. Hence, the juxtaposition of explanatory models is evidenced when the therapist uses, at the same time, behavioral, psychoanalytical, constructivist and social constructionist schools as practical guides.

Thus, again, we emphasize the tension that emerges when the therapist uses propositions with distinct epistemological foundations, like in the case of social constructionism in relation to behavioral and psychoanalytic propositions for example (Dickerson, 2010).

\section{Reflections on Conciliatory and Eclectic Discourses}

In view of the complex nature of the theoretical panorama of FT, in this item, we address reflections with a pragmatic focus that intends to grant visibility to the implications of these discourses in clinical practice and in the field of FT.

First, the search to enhance the clinical practice is the clearest aspect in the use of conciliatory and eclectic discourses. The choice to use distinct theoretical models is intended to enhance the professional action by offering multiple family care resources, in which the therapist intends to construct a theoretically grounded practice.

In addition, the conciliatory-explanatory and eclectic discourses raise important reflections on the peripheral place social constructionism can assume in these discourses, which can make social constructionism diluted and lacking depth in terms of its teaching and understanding in FT training and practice.

Thus, both conciliatory-explanatory and eclectic discourses indicate a form of articulation discussed by Féres-Carneiro and Ponciano (2005), in which the therapist comprehends the theoretical development in FT field, although it is unclear if he/she comprehends the theoretical ruptures involved in some of these theories. 
The training tradition in FT also plays an important role in the analysis of these discourses. Overall, the training programs intend to teach the different perspectives and frameworks present in the field of FT. In this process, teachers encourage the students to experience the use of different approaches in their clinical practice, or encourage them to use a specific approach aligned with the institute's theoretical orientation. Thus, social constructionism tends to be one among the different perspectives to be taught in the course, and is usually discussed in a specific module. That arouses some reflections: how do the training traditions in FT contribute to the construction of the conciliatory-constructionist, reflexive, explanatory and eclectic discourses in FT practice? What type of dissemination and use of social constructionism do we produce when we consider it as yet another approach in the field of FT?

In that sense, we highlight the relevance of the distinction proposed by Dickerson (2010) regarding the practices informed by social constructionism and practices with a social constructionist perspective. According to the author, the former are sensitive to the construction process of meanings with the clients, but do not see this process as historically located, which would imply the consideration of meanings as local and culturally situated. Differently, the practices with a social constructionist perspective assume a stance based on the social construction of knowledge, conceiving the meanings as fluid, dynamic and always open to transformations.

Another aspect to be highlighted is the dilemma created when therapists take social constructionism by its theoretical and epistemological aspects more than its practical orientation. What limits do we produce when we consider only the theoretical aspects of constructionism? And what limits do we create when we consider it as a practical guide, detached from its theoretical background? How can the dichotomy between theory and practice be overcome in the teaching and use of the social constructionist propositions?

In short, we consider that it is not about defending theoretical purism, in which the therapist should be faithful only to a certain theoretical perspective. This suggestion would invite to a stiffening and impoverishment of clinical practice by reducing the therapist's resources, besides going against the integrative trends currently present in the field. It is not about favoring "hybridism" either, in which the professional can and should use different theories regardless of how this use takes place. We consider that the reflections addressed in this article indicate the importance of reflecting on how these different discourses are present in clinical practice, providing us with indicators on the movement and current evolution of FT in Brazilian contexts.

We acknowledge that these questions echo challenges that have long been present in the reflections of the professionals involved in FT. Nevertheless, we find it relevant to appoint them as marks of existing tensions in the field regarding the way explanatory models are used in practice, including theoretical discussions in the social constructionist sphere (McNamee, 2008).

The matters we discuss in this article are complex and reflect the diversity of the FT field. We acknowledge that the scope of this article ignores several aspects involving the the- oretical basis of family therapists' clinical practice. Among the research limits, we emphasize that, being based on therapists' narratives about their clinical practice, the analysis does not consider the professionals' action in situ, when they interact with the family and construct their interventions. In this sense, the research does not address the nuances and details of professional action in the therapeutic process. Based on narratives about practice, the article highlights different discourses that construct possibilities for the use of theories and techniques in FT.

In the context of these challenges, we propose ways of action in the spheres of professional practice in FT and the family therapist's stance. In the professional midst, we underline the importance for the family therapists of studying and knowing the history of FT, which can invite them to understand the historical development and ruptures that defined different ways to understand the family and its relations. It also permits understanding the knowledge production as a historical, cultural and social process, evidencing the local and situated nature of the theories and practices.

Concerning the therapists' activities in their singular practice, we echo Dickerson's propositions (2010) when she discusses the importance of having a practice informed by an epistemological investigation about his/her own actions, in which the therapist is able to identify the premises that guide his/her questions, comments, assumptions and so on. According to Dickerson (2010), this awareness is something that the therapist should do in an attentive and intentional manner, and demands reflection and constant attention. As a result, the congruence between the practice employed and the underlying theories offer a stance that go against a position in which the therapist uses "whatever works".

Finally, we reaffirm that the analysis in this study was focused on the use of different discourses and their implications for the practice and dissemination of the social constructionist ideas among the participants. In line with this understanding, the reflections here proposed concern the discourses present in the field of FT and the future developments that can be envisioned by the therapists in their daily practices.

\section{References}

Andersen, T. (1991). The reflecting team: Dialogues and dialogues about dialogues. New York, NY: W. W. Norton.

Andersen, T. (1993). See and hear, and be seen and heard. In S. Friedman (Ed.), The new language of change: Constructive collaboration in psychotherapy (pp. 303-322). New York, NY: Guilford.

Anderson, H. (2012). Collaborative relationships and dialogic conversations: Ideas for a relationally responsive practice. Family Process, 51(1), 8-24. doi:10.1111/j. 1545-5300.2012.01385.X

Anderson, H., \& Burney, J. P. (n.d.). Collaborative Inquiry: A postmodern approach to organizational consultation. Re- 
trieved from http://www.taosinstitute.net/Websites/taos/ files/Content/5692909/CollabInquiry.pdf

Breunlin, D., \& Jacobsen, E. (2014). Putting the "family" back into family therapy. Family Process, 53(3), 462-475. doi:10.1111/famp.12083

Burr, V. (2003). An introduction to social constructionism (2nd ed.). New York, NY: Routledge.

Dickerson, V. C. (2010). Positioning oneself within an epistemology: Refining our thinking about integrative approaches. Family Process, 49(3), 349-368. doi:10.1111/j. 1545-5300.2010.01327.x

Féres-Carneiro, T., \& Ponciano, E. L. T. (2005). Articulando diferentes enfoques teóricos na terapia familiar [Articulating different theoretical views in family therapy]. Revista Interamericana de Psicología, 39(3), 439-488. Retrieved from http://www.psicorip.org/Resumos/PerP/RIP/RIP036a0/RIP03951.pdf

Flaskas, C. (2011). Frameworks for practice in the systemic field: Part 2 - Contemporary frameworks in family therapy. Australian and New Zealand Journal of Family Therapy, 32(2), 87-108. doi:10.1375/anft.32.2.87

Flaskas, C. (2016). Relating therapeutically in family therapy: Pragmatics and intangibles. Journal of Family Therapy, 38(1), 149-167. doi:10.1111/1467-6427.12108

Gergen, K. J. (1985). The social constructionism movement in modern psychology. American Psychologist, 40(3), 266-275. doi:10.1037/0003-066X.40.3.266

Gergen, K. J. (2015). From mirroring to world making: Research as future forming. Journal for the Theory of Social Behaviour, 45(3), 287-310. doi:10.1111/jtsb.12075

Guanaes, C. (2006). A construção da mudança em terapia de grupo: Um enfoque construcionista social [The construction of change in group therapy: A social constructionist approach]. São Paulo, SP: Vetor.

Guanaes-Lorenzi, C., Moscheta, M., Corradi-Webster, C. M., \& Souza, L. V. (Orgs.). (2014). Construcionismo social: Discurso, prática e produção do conhecimento [Social constructionism: Discourse, practice and knowledge production]. Rio de Janeiro, RJ: Instituto Noos.

Kaslow, F. (2011). Family therapy. In J. C. Norcross, G. S. VandenBos, \& D. K. Freedheim (Eds.), History of psychotherapy: Continuity and change (2nd ed., pp. 497-504). Washington, DC: APA.

Lebow, J. (1997). The integrative revolution in couple and family therapy. Family Process, 36(1), 1-17. doi:10.1111/ j.1545-5300.1997.00001.x

Lebow, J. (2014). Foundations of couple and family therapy. In Couple and family therapy: An integrative map of the territory (pp. 3-23). Washington, DC: APA.

McNamee, S. (2004). Promiscuity in the practice of family therapy. Journal of Family Therapy, 26(3), 224-244. doi:10.1111/j.1467-6427.2004.00280.x
McNamee, S. (2008). Um estudo socioconstrucionista da expertise terapêutica [A social construcionist exploration of therapeutic expertise]. Nova Perspectiva Sistêmica, 17(31), 35-43.

McNamee, S., \& Gergen, K. J. (1992). Therapy as social construction. London, United Kingdom: Sage.

McNamee, S., \& Hosking, D. M. (2012). Research and social change: A relational constructionist approach. New York, NY: Routledge.

Nicolò, A. M., Benghozi, P., \& Lucarelli, D. (Eds.). (2014). Families in transformation: A psychoanalytic approach. London, United Kingdom: Karnac Books.

Pinheiro, O. (2013). Entrevista: Uma prática discursiva [Interview: A discursive practice]. In M. J. P. Spink (Org.), Práticas discursivas e produção de sentidos: Aproximações teóricas e metodológicas [Discursive practices and meaning production: Theoretical and methodological approaches] (pp. 183-214). São Paulo, SP: Cortez.

Ponciano, E. L. T., \& Féres-Carneiro, T. (2006). Terapia de família no Brasil: Uma visão panorâmica [Family therapy in Brazil: An overview]. Psicologia: Reflexão e Crítica, 19(2), 252-260. doi:10.1590/s0102-79722006000200011

Prati, L. E., \& Koller, S. H. (2012). Práticas de terapia de família no Brasil [Practices of family therapy in Brazil]. In M. N. Baptista \& M. L. M. Teodoro (Orgs.), Psicologia de familia: Teoria, avaliação e intervenção [Family Psychology: Theory, evaluation and intervention] (pp. 264-280). Porto Alegre, RS: Artmed.

Rhodes, P. (2012). Nothing to fear? Thoughts on the history of family therapy and the potential contribution of research. The Australian and New Zealand Journal of Family Therapy, 33(2), 171-182. doi:10.1017/aft.2012.18

Snyder, D. K., \& Balderrama-Durbin, C. (2012). Integrative approaches to couple therapy: Implications for clinical practice and research. Behavior Therapy, 43(1), 13-24.

Spink, M. J., \& Medrado, B. (2013). Produção de sentidos no cotidiano: Uma abordagem teórico-metodológica para análise das práticas discursivas [Production of meaning in everyday life: A theoretical and methodological approach for discursive practices analysis]. In M. J. Spink (Org.), Práticas discursivas e produção de sentidos no cotidiano: Aproximações teóricas e metodológicas [Discursive practices and meaning production] (pp. 22-41). São Paulo, SP: Cortez. (Original publicado em 1999).

Spink, M. J. P., \& Menegon, V. M. (2013). A pesquisa como prática discursiva [Research as discoursive practice]. In M. J. P. Spink (Org.), Práticas discursivas e produção de sentidos no cotidiano: Aproximações teóricas e metodológicas [Discursive practices and meaning production] (pp. 42-70). São Paulo, SP: Cortez. (Original publicado em 1999).

Sutherland, O., \& Strong, T. (2011). Therapeutic collaboration: A conversation analysis of constructionist therapy. Journal of Family Therapy, 33(3), 256-278. doi:10.1111/j. 1467-6427.2010.00500.x 
White, M. (2007). Maps of narrative practice. New York, NY: W. W. Norton.

White, M., \& Epston, D. (1990). Narrative means to therapeutic ends. New York, NY: W. W. Norton.

Gabriela Silveira de Paula-Ravagnani is a Ph.D. student in the Graduate Program in Psychology at Faculdade de Filosofia, Ciências e Letras de Ribeirão Preto, Universidade de São Paulo.

Carla Guanaes-Lorenzi is a Professor of the Faculdade de Filosofia, Ciências e Letras de Ribeirão Preto, Universidade de São Paulo.

Emerson Fernando Rasera is a Professor at the Instituto de Psicologia, Universidade Federal de Uberlândia.

Received: May 31, 2016

1st Revision: Aug. 23, 2016

Approved: Nov. 22, 2016

How to cite this article:

Paula-Ravagnani, G. S., Guanaes-Lorenzi, C., \& Rasera, E. F. (2017). Use of theoretical models in family therapy: Focus on social constructionism. Paidéia (Ribeirão Preto), 27(67), 84-92 doi: 10.1590/1982-43272767201710 